\title{
V
}

\section{ANNOUNCEMENTS AND AWARDS}

During the current academic year the Trustees have received several gifts of academic interest which I have the pleasure of announcing on this occasion:

THE GAVIN HAMILTON LIBRARY

Mrs. Gavin Hamilton of Houston has donated to the Rice Institute the library of her husband, the late Dr. Gavin Hamilton. The library consists of about five hundred publications representing Dr. Hamilton's professional interests in anatomy, physiology, and surgery. With the collection Mrs. Hamilton has given several volumes of general and local interest.

PUBLIC LECTURES IN MEMORY OF THE LATE

DR. STOCKTON AXSON

Donors who wish to remain anonymous have made provision for the early delivery of three public lectures at the Rice Institute as a memorial to the late Professor Axson. These lectures will be delivered in the course of the next twelve months at the convenience of a distinguished American scholar who has accepted the appointment.

MATHEMATICAL WORKS FOR THE RICE LIBRARY

Miss Christine O. Schultz, a graduate of the Rice Institute and teacher of mathematics in the public schools of Houston, has given the sum of one hundred dollars to be used for 


\section{Twenty-Eighth Annual Commencement}

additions to the collection of rare books on mathematical subjects in the Rice Institute Library.

SPANISH BOOKS FOR THE RICE LIBRARY

The Spanish Club of the Rice Institute of 1942 has given the sum of seventy-five dollars for investment in United States War Bonds which at their maturity are to be used for the purchase of additional books in the Spanish language for the Rice Institute Library.

\section{GIFTS TO STUDENT LOAN FUND}

Since 1915 there has been built up through individual gifts a small student loan fund administered by the Bursar of the Institute through the President's Office. During the current academic year an anonymous donor has given $\$ 2500$ to this loan fund, and Mr. Charles E. Merrill of New York has donated to the same fund the sum of $\$ 300$.

We gratefully acknowledge all these gifts, thank God, and take courage.

I now have the privilege of announcing the awards of scholarships for the coming academic year, and in the order of the founding of the several scholarships and awards:

\section{SCHOLARSHIPS AWARDED FOR $1943-44$ \\ THE GRAHAM BAKER STUDENT \\ Nelson James Terrell, Jr., of the Senior Class}

HONORABLE MENTION FOR THE GRAHAM BAKER STUDENTSHIP (alphabetical)

William Henry Burke, of the Junior Class

Doris Hoag Clark, of the Senior Class

Nelson Mark Duller, Jr., of the Junior Class 


\section{Announcements and Awards}

Robert Fearn Lusk, Jr., of the Senior Class

William Roger Tobola, Jr., of the Junior Class

THE HOHENTHAL SCHOLARS

(alphabetical)

Mary Clarke Jarvis, of the Junior Class

Riki Kobayashi, of the Senior Class

Clarence Bernard Scotty, of the Senior Class

Three Hohenthal Scholarships have been reserved for award at the end of the coming academic session.

THE SCHOLAR OF THE JOHN MCKNITT ALEXANDER CHAPTER

DAUGHTERS OF THE AMERICAN REVOLUTION

Mary Elizabeth Baxter, of the Senior Class

THE AXSON CLUB'S ELLEN AXSON WILSON SCHOLAR

Elizabeth Ann Anderson, of the Senior Class

THE ELIZABETH BALDWIN LITERARY SOCIETY SCHOLAR

Patricia Mae Nyberg, of the Senior Class

THE PALLAS ATHENE LITERARY SOCIETY SCHOLAR

Marie Virginia Barrett, of the Sophomore Class

THE DANIEL RIPLEY SCHOLAR

Walter Russell Hearn, of the Sophomore Class

One Daniel Ripley Scholarship reserved.

THE JUNIOR ENGINEERING SCHOLAR

Robert Fearn Lusk, Jr., of the Senior Class

THE EDITH RIPLEY SCHOLAR

Muriel Jean Greenman, of the Sophomore Class

Two Edith Ripley Scholarships reserved.

THE MARY PARKER GIESEKE SCHOLAR

Scholarship reserved. 


\section{Twenty-Eighth Annual Commencement}

THE THOMAS AUBREY DICKSON AND PAULINE MARTIN DICKSON

$$
\text { SCHOLAR }
$$

Scholarship reserved.

THE FRIENDS OF RICE SCHOLARS

Scholarship reserved.

THE CHAPMAN-BRYAN MEMORIAL SCHOLAR

Alison Campbell Croom, of the Junior Class

THE LADY WASHINGTON TEXAS CENTENNIAL AWARD

Scholarship reserved.

THE AXSON CLUB'S KATIE B. HOWARD SCHOLAR

Marjorie Jane Barnes, of the Senior Class

THE SAMUEL S. ASHE SCHOLAR

William Freeman Love, of the Sophomore Class

THE ENGINEERING ALUMNI SCHOLAR

John Raymond Eckel, of the Senior Class

THE THOMAS R. FRANKLIN AND JULIA H. FRANKLIN SCHOLARS

(alphabetical)

Betty Jane Fagan, of the Senior Class

Katherine Martha Fischer, of the Senior Class

James William Glanville, of the Senior Class

Richard Colt Goodson, of the Junior Class

George Harold Hacke, of the Senior Class

Richard Henry Parker, of the Senior Class

Eldon Armstrong Siegman, of the Junior Class

Margaret Patricia Sullivan, of the Junior Class

Katharine Louise Wakefield, of the Senior Class

Albert Ewald Woelfel, of the Junior Class

Seven Franklin Scholarships reserved. 


\section{Announcements and Awards 153}

THE " $R$ " ASSOciation SCHOLAR

Scholarship reserved.

THE PRE-MEDICAL SOCIETY SCHOLAR

Scholarship reserved.

THE AMERICAN PETROLEUM INSTITUTE SCHOLAR

William Lamar Davis, Jr., of the Senior Class

THE MAX AUTREY MEMORIAL SCHOLARS

(alphabetical)

Stuart Creighton Mut, of the Junior Class

William Delany Walker, Jr., of the Junior Class

One Max Autrey Memorial Scholarship reserved.

THE LADY GEDDES PRIZE IN WRITING

Maralyn Maureen McCurdy, of the Sophomore Class

THE SAMUEL FAIN CARTER FELLOW

Vincent Frederick Cowling, B.A. (Rice) I94I, M.A. (Rice)

I943

THE WALSH SCHOLAR IN ARCHITECTURE

Ralph Alexander Anderson, Jr., Class of 1943

HONORABLE MENTION FOR THE WALSH

SCHOLARSHIP IN ARCHITECTURE

(alphabetical)

David Mendel Keeper, Class of 1943

Thomas Shirley Simons, of the Senior Class

Due to world conditions which affect the purposes for which they were established, no awards have been made under the Traveling Fellowship in Architecture or the Mary Alice Elliott Loan Fund. 


\section{Twenty-Eighth Annual Commencement}

The awards of the two James A. Baker and Alice Graham Baker Graduate Fellowships, of the Catharine Withers Roper and Benjamin E. Roper Graduate Fellowship, and of the Walter B. Sharp Fellowship have been deferred.

Throughout its history the Institute has maintained from its own funds a number of fellowships and assistantships in various departments. The announcement of these appointments will as usual be carried in the current catalogue. 